\title{
Study on the post-partum disorders and their relationship with the reproductive performance in Iraqi cow-buffaloes
}

\author{
M.A. Rahawy \\ Department of Surgery and Theriogenology, College of Veterinary Medicine, University of Mosul, Mosul, Iraq
}

\begin{tabular}{l} 
Article information \\
\hline Article history: \\
Received March 25, 2020 \\
Accepted May 14, 2020 \\
Available online February 22, 2021 \\
\hline Keywords: \\
Buffalo \\
Postpartum disorder \\
Calving Interval \\
Open days \\
\\
\hline Correspondence: \\
M.A. Rahawy \\
mohammedrahawy@ yahoo.com
\end{tabular}

\section{Article information}

Received March 25, 2020

Accepted May 14, 2020

Available online February 22, 2021

Keywords

Postpartum disorde

Calving Interva

M.A. Rahawy

mohammedrahawy@yahoo.com

\begin{abstract}
This study was conducted to evaluate the influence of various postpartum disorders on subsequent reproductive performance in Iraqi cow buffaloes. The data were collected from 172 buffaloes within private dairy buffaloes herd. In this study, the diagnosis and treatment of the affected cases with postpartum disorders (Retained placenta, puerperal metritis, uterine prolapse and vaginal prolapse) contributed in the data collection based on the parity, calving time and reproductive parameters (days to first estrus, open days, service per conception, intervals between estrus and calving interval). Cow buffaloes were divided according to their postpartum disorders into 5 groups: first group (healthy), second group (retained placenta), third group (puerperal metritis), forth group (uterine prolapse) and fifth (vaginal prolapse). The results of this study showed that a total of $74.42 \%$ of the cow buffaloes had normal post-partum and open days 121.9 days with resumed ovarian cyclic activity within 77.41 days, increased incidence of G2, G3, G4 and G5 were 9.88, 6.97, 6.97, 5.23 and $3.48 \%$, respectively. Open days were significantly longer in buffaloes in groups 2, 3,4 and 5 compared to healthy group. In conclusions, early postpartum disorders manifested by increased days to first estrus, calving interval, days open and service per conception were longer than healthy cases in the Iraqi cow- buffaloes.
\end{abstract}

DOI: 10.33899/ijvs.2020.126771.1387, (C2021, College of Veterinary Medicine, University of Mosul.

This is an open access article under the CC BY 4.0 license (http://creativecommons.org/licenses/by/4.0/).

\section{Introduction}

Fertility in cow-buffalo has been declined for the last decades. Several factors are contributing in this declined. Good reproductive performance in buffaloes is the key to dairy economics. Various studies have identified decreased reproductive performance is regarded as a major cause of decreased production efficiency in cow buffaloes industry, caused by greater costs of decreased milk yield per year, veterinarian involvement, and finally herds replacement. The reproductive performance of cow-buffalo herds can be assessed by using different indicators. Time interval measurements have been used as reproductive performance indicators and many of these measurements are established on the cows' buffalo individual calving date such as interval from calving to first service and calving interval. Calving interval in cow's buffalo is ranged from 471-585 days (1).
Therefore, cow- buffalo normally gives two calves in three years (2). Calving interval is based on two components: an interval from calving to conception and gestation period. Thus calving to conception is regarded as the main important factor affecting fertility in cow-buffalo. One of the major causes of the declined reproductive efficiency in the cowbuffalo is the duration between calving and the next conception. However, this is also influenced by environmental factors, management (accuracy of heat detection, use of proper insemination technique and appropriate herd health policies) as well as biological factors (3).

Post-partum reproductive disorders in buffalo are usually multi-factorial problems, which based on their nature and severity in varying degrees of abnormal reproductive performance. Toxic puerperal metritis is an important postpartum disease in cow buffaloes with a prolonged calving 
interval and open days, resulting in high economic losses (4). Moreover, retained placenta delays uterine involution of cow buffalo and thereby reduces fertility (5). A prolapse was the abnormal relocation of organs (uterine, vagina) from its normal anatomical position occur at near the time of delivery (6). The incidence rates of retained placenta, toxic puerperal metritis, uterine prolapse and vaginal prolapse were 16.03, $8.9,7.63$ and $2.29 \%$ respectively in Iraqi cow- buffaloes (7).

Postpartum uterine disorders in cow- buffalo's herds have negative impact of reproductive efficiency of the buffalo herds (8). Resulting increased veterinary costs because of lower reproduction, culling rates associated with decrease milk production and longevity of cow- buffaloes. As the rate of postpartum disorders increased the incidence of ovarian dysfunction was increased following the postpartum disorders in buffaloes (9). Several studies have considered the influence of uterine complications during postpartum period on reproductive performance in high yielding dairy cows (10). However, there is not enough data on the influence of postpartum uterine complications on reproductive performance in cow's buffalo. For that reason this study was aimed to investigate the post-partum disorders and their effects on first estrus after calving, calving interval, length of gestation, open days and number of service per conception in Iraqi cow buffaloes.

\section{Materials and methods}

Data were collected from 172 Lactating Iraqi cowbuffaloes were calved from October 2017 to November 2019, aged 6 to 14 years in large private herds in Mosul city, Nineveh province. Animals were kept in an open house and were fed on concentrate feed mixture along with clover hay twice daily, there was free access to water. Animal were milked manually two times per day.

Data based on the reproductive including (days to first estrus, service per conception, intervals between heats, open days, calving interval and gestation period) of the present study records were collected from the dairy buffalo's herd which was normally calved. The definition of reproductive performance parameters were used in this study is described in table 1 .

Table 1: Definition of the key reproductive parameter

\begin{tabular}{ll}
\hline Reproductive parameters & Definition \\
\hline Days to first estrus & Number of days from calving to the day of first insemination after calving \\
Open days & Interval from calving to the first conception date after calving \\
Services per conception & Number of services required for a buffaloes to get pregnant. \\
Interval between heats & Interval between estrous cycles per cows' buffalo \\
Calving interval & Number of days between two successive calving \\
\hline
\end{tabular}

Animals were classified into 5 groups according to the uterine health status into: healthy group (animals with no observation any abnormal clinical signs during post-partum period), retained placenta group, toxic puerperal metritis group, uterine prolapse group and vaginal prolapse group. The post-partum disorders were diagnosed on a routine veterinary visit (clinical signs and clinical examinations). The placenta was considered retained if the retention of the fetal membrane occurs within over 12 hours $(11,12)$. Toxic puerperal metritis was diagnosed depending on the prevalence of the inflammation of uterine layers with enlarged uterus in the first 10-14 days after calving associated with general toxemia, red brown fetid uterine discharge, fever up to $39.5^{\circ} \mathrm{C}$, and decrease of milk production (13).

Uterine prolapse was diagnosed when protrusion of uterine completely or partially from vulva While the diagnosis of vaginal prolapse when protrusion of vagina from vulva. The treatments of such affected cases were done according to routine treatment protocol of each disorder. All animals were showed twice daily for heat detection at 3.00 a.m. and 6.00 p.m. by using a fertile bull with natural mating conducted estrus. Therefore, pregnancy diagnosis through rectal palpation was adopted subsequently after two months
(6). Calving interval, open days and number of services per conception were recorded for each cow- buffalo.

\section{Statistical analysis}

The cow buffalo herd data were collected analysis with Statistical Package for the Social Sciences $1^{\text {st }}$ edition (SPSS Brief Guide, SPSS Inc, Chicago, USA). Unbalanced ANOVA, followed by multiple comparisons, was used to determine the differences of reproductive performance (days to first service, open days, service per-conception, interval between heats, and calving interval) between healthy groups and groups with different uterine disorders. All variables were kept in this model with significant attributes at $P<0.05$. All data are presented as mean \pm SE.

\section{Results}

A total of number 172 cow-buffaloes, $74.42 \%$ of the cow- buffaloes were healthy and devoid from post-partum uterine disorders and $25.58 \%$ cow-buffaloes had abnormal uterine disorders during post-partum period. The healthy cow -buffaloes had normal open days 121.9 day post-partum and resumed ovarian cyclic activity within 77.41 days postpartum. 
The results showed that days to Days to first estrus (DFS) was significantly deference between groups of animals (Table 2). Healthy cows- buffalos had significantly shorter DFS compared to groups 2, 3, 4 and 5 by about 87 days, 66 days, 62 days and 58 days, respectively. Cows buffaloes experienced with retained fetal membrane need longer period to return estrous cycle after calving 164.27 days compared to other groups with postpartum disorders (Table 2 ). The lowest value was seen in groups of animals with vaginal prolapse 135.36 days (Table 2).

Cows- buffaloes experienced with retained fetal membrane, puerperal metritis, uterine prolapse and vaginal prolapse had significantly longer calving interval (CI) compared to healthy cows by 107 days, 86 days, 76 days and 69 days, respectively (Table 2). The results showed those calving intervals were recorded in animals suffered from the retained placenta showed that there were highest days to consequent calving value 547.77 days, while the lowest one was attained in the healthy group 441.11 days.
In terms of open days, post-partum uterine complications had significantly effect on open days (Table 2). Cow's buffaloes with retained fetal membrane had significant longer period of open days about 103 day compared to healthy groups. Cow- buffaloes with uterine prolapse, puerperal metritis and vaginal prolapse had longer open days compared to healthy animals about 81 days, 76 days and 71 days, respectively (Table 2). It is interesting to note that there was no significant difference in terms open days among groups 3, 4 and 5 (Table 2).

Referring to the effect of the post-partum disorders on the number of service per conception, the results showed that there was significantly different among different cow buffalo's groups with the control group during the early postpartum stage (Table 2). In addition, Cow- buffaloes with retained fetal membrane had higher number of service per conception about 1 service as compared to healthy groups (Table 2). However, there was not significant seen among other groups 3, 4 and 5 (Table 2).

Table 2: Effect of postpartum disorders on Iraqi cow- buffaloes reproductive performance

\begin{tabular}{lcccccc}
\hline & buffaloes & \multicolumn{5}{c}{ Mean \pm SE } \\
\cline { 3 - 7 } Groups & $\begin{array}{c}\text { incidence } \\
\mathrm{n}(\%)\end{array}$ & $\begin{array}{c}\text { Day to first } \\
\text { estrous cycle }\end{array}$ & $\begin{array}{c}\text { Calving } \\
\text { interval }\end{array}$ & $\begin{array}{c}\text { Length of } \\
\text { gestation }\end{array}$ & $\begin{array}{c}\text { Open } \\
\text { days }\end{array}$ & $\begin{array}{c}\text { No of } \\
\text { service }\end{array}$ \\
\hline Group1 (Healthy) & $128(74.42)$ & $77.41 \pm 3.58^{\mathbf{a}}$ & $441.11 \pm 6.36^{\mathbf{a}}$ & $319.21 \pm 1.24^{\mathbf{a}}$ & $121.9 \pm 5.17^{\mathbf{a}}$ & $2.12 \pm 0.23^{\mathbf{a}}$ \\
Group2 (Retained Placenta) & $17(9.88)$ & $164.27 \pm 3.38^{\mathbf{b}}$ & $547.77 \pm 6.86^{\mathbf{b}}$ & $322.18 \pm 3.89^{\mathbf{a}}$ & $225.59 \pm 2.63^{\mathbf{b}}$ & $2.92 \pm 0.32^{\mathbf{b}}$ \\
Group3 (puerperal metritis) & $12(6.97)$ & $142.94 \pm 4.16^{\mathbf{c}}$ & $526.82 \pm 7.42^{\mathbf{c}}$ & $321.42 \pm 3.23^{\mathbf{a}}$ & $203.4 \pm 2.16^{\mathbf{c}}$ & $2.86 \pm 0.56^{\mathbf{b}}$ \\
Group4 (uterine prolapse) & $9(5.23)$ & $139.32 \pm 2.87^{\mathbf{c}}$ & $517.27 \pm 6.38^{\mathbf{c}}$ & $319.38 \pm 2.87^{\mathbf{a}}$ & $197.89 \pm 4.37^{\mathbf{c}}$ & $2.79 \pm 0.27^{\mathbf{b}}$ \\
Group5 (Vaginal prolapse) & $6(3.48)$ & $135.36 \pm 4.27^{\mathbf{c}}$ & $509.74 \pm 4.69^{\mathbf{c}}$ & $318.84 \pm 2.54^{\mathbf{a}}$ & $192.9 \pm 3.76^{\mathbf{c}}$ & $2.74 \pm 0.21^{\mathbf{b}}$ \\
\hline Total & 172 & & & & &
\end{tabular}

Values with a,b,c: different superscript letters on the same column referred to significant differences at $\mathrm{P}<0.05$.

\section{Discussion}

The objective of this study was to investigate the association between post-partum uterine disorders on reproductive performance in Iraqi cow-buffaloes. The importance of the period immediately following calving in the reproductive life cycle of a cow-buffalo could be attributed to the influence on reproductive efficiency. A normal uterine involution and the re-establishment of the ovarian function are associated with post-partum disorders that are critical to acquire short period of time from calving to conception that is required for the improvement of milk production (3). It has been recently investigated that cows with endometritis had negative impact on the postpartum ovarian cyclicity in dairy cows (10).

This study showed that there was significant correlation between reproductive performances and the post-partum disorders in Iraqi cow buffaloes. This study found that healthy groups of animals exhibited $74.42 \%$ resumed their ovarian cyclic activity within 77.41 days post-partum. In agreement with Shah et al. (1) who found that $84.2 \%$ of the buffaloes that had resumed ovarian cyclicity within 100 days of normal postpartum.
The present study reported that the incidence of retained placenta was nearly $10 \%$ which is nearly the same $9 \%$ as reported by Purohit et al. (14). The incidence rate of toxic puerperal metritis in this study was about $7 \%$, which is much lower $17 \%$ reported by Azawi et al. (12) in Iraqi cowsbuffalo. This study found that he incidence of uterine prolapse was $5.23 \%$, which is lower than $7.73 \%$ reported by Purohit et al. (14) in Pakistan. The incidence rate of vaginal prolapse in this study was $3.48 \%$, which is nearly to the previous study by Rahawy (7), who recorded $2.29 \%$ in Iraqi cow-buffaloes.

It is interesting to note that this study reported that cow's buffaloes with postpartum uterine disorders had significantly longer days to first service, open days and higher number of service preconception compared to healthy groups of animals. This study found that retained fetal membrane regarded as the main factor which affects the reproductive performance within other uterine disorders. This study agreed with the previous studies Manoja et al. (9) they reported that retained placenta had significant impact on reproductive performance of Murrah buffaloes. The obvious higher productive losses associated with retained placenta 
could be a considerable risk cause for toxic puerperal metritis in Iraqi cow-buffaloes (15).

In addition, the negative effect of both reproductive risks (retained placenta and toxic puerperal metritis) on endometrial layer seemed to alter the ovarian activity leading to infertility in cow-buffaloes (16). The post-partum disorders result in keeping the cervical canal opened with distended uterine lumen and eventually leading to reduced normal uterus contractions associated with bacterial contamination of the uterine tissue from environmental contaminants (11).

The results showed that puerperal metritis had effect on reproductive performance. Animals with metritis had significantly longer open days about 81 days and higher number of service per conception about (1 service) compared to control cows. This is similar to the previous study by Harun-Or-Rashid et al. (17) showed a significant increase in the calving intervals and number of services per conception in cow buffaloes affected with metritis. Furthermore, this study found that cows buffaloes exhibited with uterine prolapse had longer open days about 198 days and higher number of service preconception about 2.8 service compared to control cow's buffaloes 122 days and 2.12 services. This is agreed with Rahawy (7) that observed that buffaloes had longer open days 184.6 days in cow buffaloes in south Iraqi buffaloes suffering from uterine prolapse. In buffaloes, it was considered that complicated cases of uterine prolapse may involve a significant effect on service period and number of services per conception (16).

Moreover, the incidence of vaginal prolapse $3.48 \%$ which nearly to $2.29 \%$ the recorded Rahawy (7) in Iraqi. The results of this study reported that cow buffaloes with vaginal prolapse had significantly longer interval from calving to the first estrus after postpartum, had longer calving interval and higher number services per conception than the healthy group. The vaginal prolapse in cattle were occurrence an increase in calving interval open days and the number of services required per-conception subsequent in heavy economic losses (18).

\section{Conclusion}

It can be concluded the postpartum disorders had excessive effects on the reproductive performance of Iraqi cow-buffaloes. Retained placenta, puerperal metritis, uterine prolapse and vaginal prolapse result which the main factors is affecting on the reproductive performance in increased calving interval, open days and next conception. Low reproductive performance was observed in the dairy cowbuffaloes suffered from postpartum disorders.

\section{Acknowledgement}

The authors are very grateful to the University of Mosul, College of Veterinary Medicine for their provided facilities, which helped to improve the quality of this work.

\section{Conflict of interest}

The author has no conflict of interest.

\section{References}

1. Shah NH. Prolonged calving intervals in the nili ravi buffalo. Ital $\mathbf{J}$ Anim Sci. 2007;6(2):694-696. Doi: 10.4081/ijas.2007.s2.694

2. Parlato $E$ and Zicarelli L. Effect of calving interval on milk yield in Italian buffalo population. J Buffalo Sci. 2016;5:18-22. Doi: 10.6000/1927-520X.2016.05.01.3.

3. Dawod A, Mostafa I, El-Baz H, Abdel-Hamid T, Fathala MM. Risks of some postpartum uterine affection on reproduction and milk yield of high yielding dairy cows. J Vet Sci Technol. 2015;6:4. Doi: 10.4172/2157-7579.1000239.

4. Karimi HI, Mahdavi N, Shadi S. Histological structure of Azerbaijan buffalo Uterus. Inter J Anim Res. 2017;1:6. DOI:10.28933/ijar-201709-2501

5. Ganaie BA, Japheth KP, Ali M, Lone SA, Mir SH, Malik TA. An insight into the pathophysiology, preventive and treatment strategies of retained fetal membranes in bovines- a review. J Anim Health Prod. 6(2):62-72. http://dx.doi.org/10.17582/journal.jahp/2018/6.2.62.72

6. Yohannes B. and Alemu B. Reproductive Disorders in Dairy Cattle;Retrospective Study in Asella Town, Central Ethiopia. Dairy Vet Sci J.2019;9(3):1-6. DOI: 10.19080/JDVS.2019.09.555767

7. Rahawy MA. Reproductive disorders in Iraqi buffalo cows in Ninavah province. The $4^{\text {th }}$ scientific conference college of Veterinary Medicine, University of Mosul.2006;89-96.

8. Bisla A, Yadav V, Dutt R, Singh D, Gahalot CG. Fertility augmentation approaches in dairy animals: A review. Inter J Curr Microbiol App Sci. 2018;7(2):2995-3007. https://doi.org/10.20546/ijcmas.2018.702.365.

9. Manoj M, Gupta AK, Mohanty TK, Muhammad Aslam MK, Dash SK. Chakravarty AK, Singh A. Effect of functional traits on subsequent reproduction performance of Murrah buffaloes in India. J Appl Anim Res. 2017:45(1):22-28 http://dx.doi.org/10.1080/09712119.2015.1102727

10. Mohammed ZA., Manna G.E., Robinson R.S. Impact of endometritis on post-partum ovarian cyclicity in dairy cows. Vet J. 2019;248: 8-13. https://doi.org/10.1016/j.tvj1.2019.03.008

11. Azawi OI, Rahawy MA, Hadad JJ. Bacterial isolates associated with dystocia and retained placenta in Iraqi buffaloes. Reprod Domest Anim. 2007;43:286-292. doi: 10.1111/j.1439-0531.2007.00892.x

12. Al-Watar BD, Lazim EH, Al-Hyani OH. Creatine kinase and $\mathrm{C}$ reactive protein as an indicator for tissue damage in the retained placenta in cows. Iraqi J Vet Sci. 2021;35(1):163-167. DOI: 10.33899/ijvs.2020.126496.1338

13. Azawi OI, Omran SN, Hadad JJ. Treatment of toxic puerperal metritis in Iraqi buffalo cows. Vet Arhiv. 2008;78:487-499.

14. Purohit GN, Arora AS, Gocher T, Gaur M, Saraswat CS, Mishra P. Uterine prolapse in buffaloes: A review. Asian Pacific J Reprod. 2018;7(6):241-247. doi: 10.4103/2305-0500.246341.

15. Azawi OI, Omran SN, Hadad JJ. Clinical bacteriological and Histo pathological study of Toxic puerperal metritis of Iraqi buffalo. J Dairy Sci. 2007. 90:4654-4660. doi:10.3168/jds.2007-0114

16. Azawi OI, Taha MB. Clinical and bacteriological study of endometritis in Iraqi buffaloes. Iraqi J Vet Sci. 2002;16:167-178

17. Harun RM, Sarkar AK, Iqbal Hasan MM, Hasan M, Juyena NS. Productive, reproductive, and estrus characteristics of different breeds of buffalo cows in Bangladesh. J. Adv. Vet. Anim. Res. 2019;6(4): 553560. http://doi.org/10.5455/javar.2019.f382.

18. Hasan T, Azizunnesa, Parvez MA, Paul P, AkterS, Faruk MO, Hossain D Correction and management of vaginal prolapse in a cow by Buhner's technique. Res J Vet Pract. 2017;5(1):1-4. DOI | http://dx.doi.org/10.17582/journal.rjvp/2017/5.1.1.4 
اشتملت على وقت الو لادة والأداء التناسلي اللاحق (عدد أيام لحدوث أول

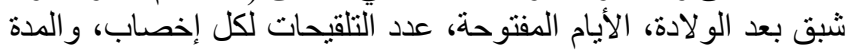

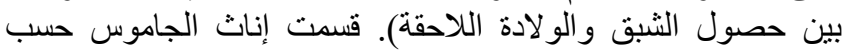

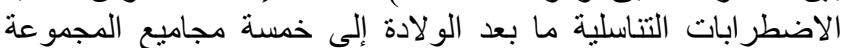

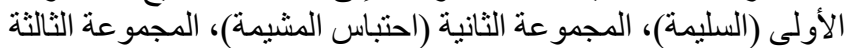

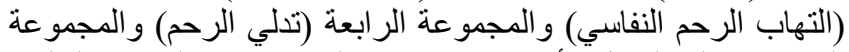

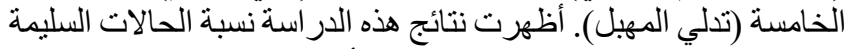

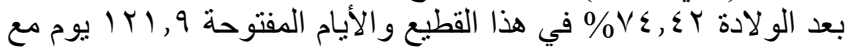

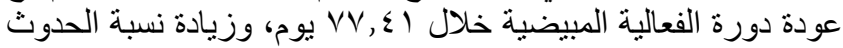

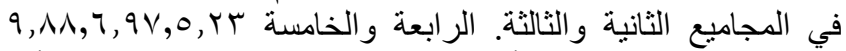

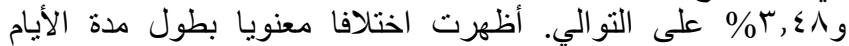

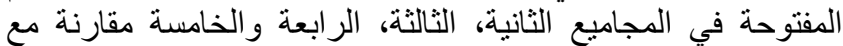

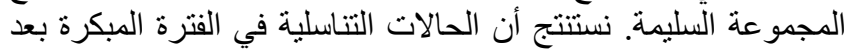

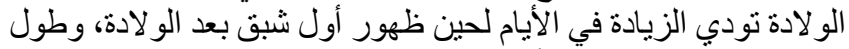

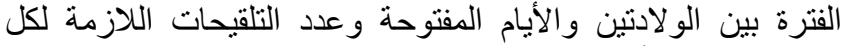

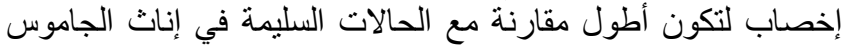

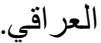

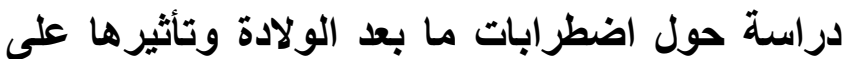
الأداء التناسلي اللاحق في إناث الجاموس العراقي محمد عبد الاله رحاوي

فرع الجراحة وعلم تناسل الحيوان، كلية الطب البيطري، جامعة

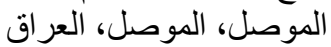

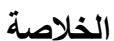

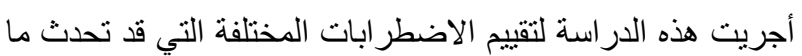

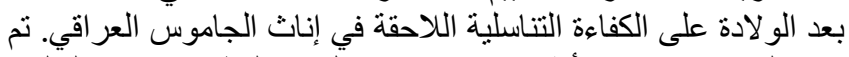

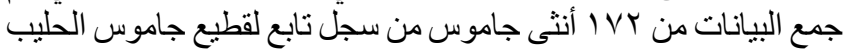

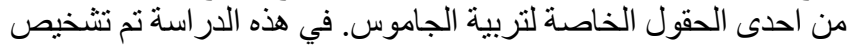

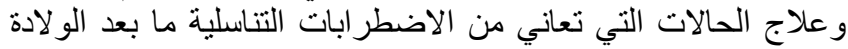

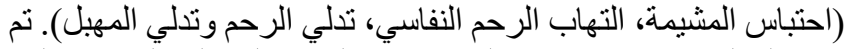
جمع المعلومات حسب قاعدة البيانات عن الكفاءة التناسلية اللاحقة والتي التي 